\title{
Prussian Blue- An Radioactive De-Corporation Agent
}

\author{
Hardeep Singh Bambra1, Mohd Mazhar ${ }^{2}$ \\ ${ }^{1}$ M.Pharm. (Quality Assurance), ${ }^{2} \mathrm{PhD}$, Research Scholar \\ 1,2Delhi Institute of Pharmaceutical Sciences \& Research, New Delhi, India
}

\begin{abstract}
How to cite this paper: Hardeep Singh Bambra| Mohd Mazhar "Prussian BlueAn Radioactive De-Corporation Agent" Published in International Journal of Trend in Scientific Research and Development

(ijtsrd), ISSN: 2456-

6470, Volume-3 |

Issue-4, June 2019,

pp.874-877, URL: https://www.ijtsrd.c om/papers/ijtsrd23

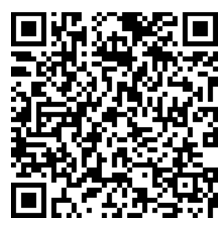

IITSRD23960
\end{abstract} 960.pdf

Copyright (C) 2019 by author(s) and International Journal of Trend in Scientific Research and Development Journal. This is an Open Access article distributed under the terms of the Creative Commons

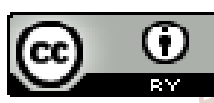

Attribution License (CC BY 4.0) (http://creativecommons.org/licenses/ by $/ 4.0$ )

\section{ABSTRACT}

During the past few years, Science \& Technology has extended to a large extent. They are mainly used in the field of medicine, diagnosis \& treatment of the various diseases. Radioisotopes are extensively used in the field of medicine, treatment \& diagnosis. But Apart from it, their major use is in the field of diagnosis. When a Human or a Living Being comes in contact with the radiations which are exerted by the radioactive elements or comes in contact with the any of the radioactive elements then it got incorporated in its body cells, tissues or organs. So, as to remove them we extensively used the de-corporation technique, which works on the phenomenon of adsorption. The agents we preferably used in the de-corporation are known as de-corporating agents. There are mainly two categories in which we have divided these decoporating agents; they are External de-corporating agents \& Internal de-corporating agents. External decorporating agents are mainly used to remove radioactive elements from the external body surfaces like skin \& the mucous membrane \& on the other side Internal de-corporating agents remove the radioactive elements from the Internal body parts, they are further classified as GI absorbers, Mobilizing agent, Blocking agent, Diluting \& Chelating agents. Prussian Blue is one of the most commonly used Internal de-corporating agent, it mainly performs their action by the absorption of the radioactive elements in the GIT, so they are also known as the GI absorbers. In US market it is marketed as 5oomg hard gelatin capsule which contains PB granules \& marketed by the Brand name of Radio-gardase. There are different nuclear disasters which we faced during the last some years like the Fukushima Nuclear Disaster, Chernobyl Nuclear Disaster, etc. Hence, we concluded that we need De- contaminating agents, so as to remove the radioactivity from the body.

Keywords: PB-Prussian blue, GI-Gastro-Intestine, US- United Estates, GIT-Gastro-Intestinal Tract, Cal-Calcium

\section{INTRODUCTION}

In the past few years, the capitalization of radionuclides in the terrain of Science \& Technology has been expanded to a large extent. They are being used in medicines, diagnosis \& treatment of the ailment. In inclusion to this, they are extensively used in biomedical research, chemistry, physics, biology \& Geosciences. Apart from the medical terrain they also have the application in the nonmedical terrain as well. Radioisotopes nowadays mainly used in Smoke detectors, detect the flaws in steel sections, to check rectitude of welds on pipes \& structures, yardsticks the thickness of paper \& plastic, restraint the density of Ice-cream \& concrete mixtures, gauge the filling extent of Cans \& Bottles in Manufacturing lines\& Sterilize Contact lens cleaning solution, Diapers, Cosmetics, Powders, Ointments, Medical Instruments, Bandages. Moreover, to reveal lead content in paints \& to scour weapons \& explosives in luggage. (Cohen Jennie et. al, 2011) Radioactive materials majorly used as the diagnostic tool to identify the status of the disease \& to minimize the need for surgery so as to reduce the risk of postoperative infection.

\section{Applications of Radioactive Elements}

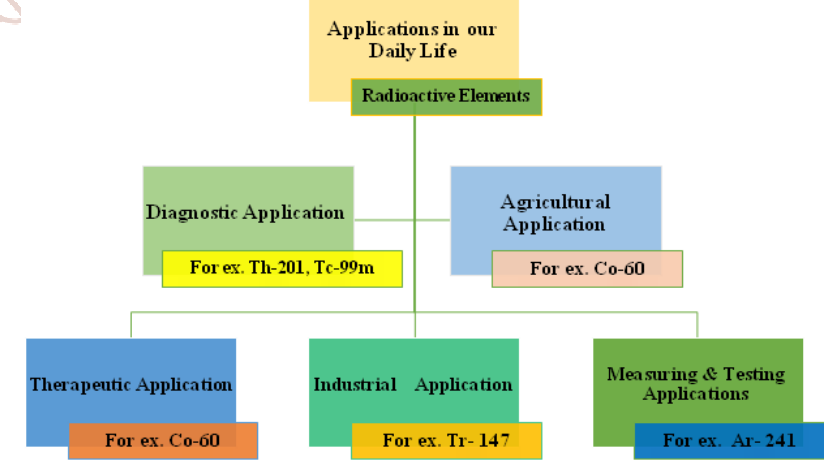

A. Diagnostic Application- They are used to observe the soft tissues \& bones inside the body, and also used to check the clogged arteries \& veins in the circulatory system.

B. Agriculture Applications- Radioisotopes are used to develop the new strains of food crops which are disease resistant, higher quality \& produce a higher yield.

C. Therapeutic Applications-They are mainly used in the treatment of Cancer by targeting the Cancerous cells. 
Teletherapy Unit device destroys malignant tumors with gamma radiations from Cobalt-60 (Co-60) radioisotopes.

D. Industrial Applications- Radioisotopes are also used to detect the depth of the well by geologists the technique is known as the Nuclear Well Logging. Radioisotopes are also used to spot the crime by spotting the trace element of poison. Radiation from the radioisotopes is also used to destroy germs, bacteria\& other harmful microorganisms which contaminate blood, medical \& food supplies.

E. Measuring \& Testing Applications- Radiation from the radioisotopes is generally used to measure the thickness \& density of the substance during the manufacturing quality control process of the substance when passes through it. It is used in the quality control of textiles, aluminum foils, metal sheets, newspaper, plastics \& photographic film, etc. (United States Nuclear Regulatory Commission, April 2000)

De-corporation of Radioactive Elements

De-corporation Agents- Those agents which are used to expel out the radioactive as well as non-radioactive elements from the body through GIT as well as from the systemic circulation. The process of de-corporation used based on some chemical reactions not on the radioactivity of the substance.

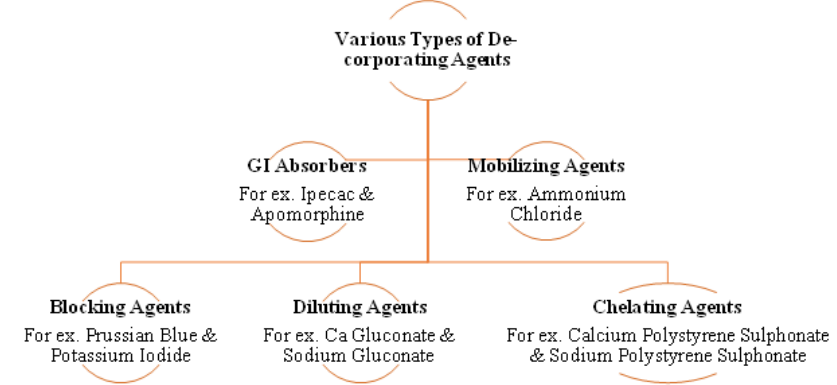

1. GI Absorbers- They perform their action by gastric lavage or by emesis.

2. Blocking Agents- They reduce the uptake of radionuclides in the target organ.

3. Diluting Agents- They are stable nuclides which are given to dilute the smaller quantities of radionuclides by competing with them at their uptake sites.

4. Chelating Agents-It forms a complex with the different ions so as to block their uptake in the tissues.

5. Mobilizing Agents- They enhance the natural elimination of the radionuclides from the body tissues.

(A Brief History of Nuclear Accidents Worldwide: Union of Concerned Scientists, Science for healthy planet \& safer world)

List of Historical Radioactive De-Corporation Cases

\begin{tabular}{|c|c|c|}
\hline $\begin{array}{c}\text { S. } \\
\text { No. }\end{array}$ & $\begin{array}{c}\text { Radionuclide } \\
\text { Contamination Cases }\end{array}$ & $\begin{array}{c}\text { Dominant Isotope } \\
\text { for de-corporation }\end{array}$ \\
\hline 1. & $\begin{array}{c}\text { Radium Dial Painters, } \\
\text { United States, Hanford }\end{array}$ & $226,228 \mathrm{Ra}$ \\
\hline 2. & $\begin{array}{c}\text { WA, United States, Los } \\
\text { Alamos }\end{array}$ & ${ }^{241} \mathrm{Amn}$ \\
\hline 3. & NM, United States & ${ }^{239} \mathrm{Pu}$ \\
\hline 4. & Goiania, Brazil & ${ }^{137} \mathrm{Cs}$ \\
\hline 5. & Chernobyl, Ukraine & ${ }^{131} \mathrm{I}$ \\
\hline 6. & $\begin{array}{c}\text { Fukushima Tragedy, } \\
\text { Japan(Recent Case) }\end{array}$ & ${ }^{131} \mathrm{I},{ }^{134,137} \mathrm{Cs}$ \\
\hline
\end{tabular}

(Waller E.A. et. al., 2002)
In military departments, de-corporation agents are used for the immediate relief of the military personnel's from the radioactive contamination, for this medical care special protocols \& training procedures are developed. Sometimes the treatment with the radionuclides leads to the undesirable side-effects to the personnel's, in that case, special attention is required for them. There are a few medical condition considerations which need to be taken into account for field treatment of contamination injuries. De-corporation treatment must come secondary to performing life-saving actions on an injured soldier. Triage of patients based primarily upon overall medical condition and secondarily upon initial bioassay indicators is crucial to the overall medical health of the deployment. Field personnel must be trained on medical and radiological triage. Administration of de-corporation agents should be with a knowledge of contraindications to drug therapy. For example, a soldier with a severe allergy to iodine would not be a good candidate for iodine prophylaxis from a reactor release scenario. For military operations in environments with potential radiological contamination scenarios, bioassay should be an integral part of the deployment. For a military deployment, it is often impossible to treat a patient in a sterile environment. In addition, all of the equipment that would be available in a civilian hospital will not be available in a military theatre, nor would it have the same mobility as military medical equipment. (Waller E.A. et. al., 2002). Insoluble Prussian Blue i.e., chemically Ferric (III) hexacyanoferrate reduce uptake of radioactive cesium \& thallium from GIT to the systemic circulation. It was firstly prepared in 1704, used as an inorganic pigment. From the 1960's it was started using as decorporating agent for radiothallium as well as for radio-cesium (Cs-134 \& Cs-137). It was majorly started used as a decorporating agent after the Chernobyl incident, 1986 \& Goiania incident, 1987. (Dominguez G. et. al., 2011). It is marketed as capsule formulation contains $0.5 \mathrm{~g}$ of insoluble Prussian blue $\& 30$ in number in each bottle packing. In the UnitedStates of America, it is marketed as Radiogardase-Cs (Radiogardase ${ }^{\circledR}$ ) \& in Europe it is marketed as Antidotum (Thallii-Heyl® distributed by Heyl Chemischpharmazeutische Fabrik GmbH, Berlin, Germany).

\section{In vitro binding efficiency of Prussian blue to cesium}

$>$ The binding efficacy if cesium to the Prussian blue depends directly on the $\mathrm{pH}$ of the environment i.e. its minimum binding efficiency is at $\mathrm{pH} \mathrm{1-2}$ and maximum binding efficiency is at $\mathrm{pH} 7.5$

$>$ The binding efficiency of cesium to Prussian blue depends directly on the ph of the environment i.e. its minimum binding efficiency is at $\mathrm{pH}$ 1-2 and maximum binding efficiency is at $\mathrm{pH} 7.5$

$>$ Increasing the exposure time and concentration of Prussian blue also in increases the binding capacity of cesium with maximum binding efficacy of $715 \mathrm{mg} / \mathrm{g}$ of PB

$>$ Storage at elevated temperatures will decrease the moisture content of Prussian blue and decreased moisture content decreases its binding efficiency to cesium

$>$ The decrease in particle size increases the binding efficiency. (IPCS evaluation of antidotes for poisoning by 5 metals and metalloids: Prussian blue Initial Draft-1994). 
In vitro binding efficacy of Prussian blue to thallium

$>$ The binding efficiency of Prussian blue increases with the increase in $\mathrm{pH}$, it has a minimum binding efficiency at $\mathrm{pH} 1$ and maximum binding efficiency at $7.5 \mathrm{pH}$.

$>$ Binding efficiency of Insoluble Prussian blue increases with the increase in exposure time and concentration with the maximum binding capacity of approximately $1400 \mathrm{mg}$ per gram of $\mathrm{PB}$

$>$ Just like cesium, the loss in the moisture content of Prussian blue on storing at elevated temperatures decreases its thallium binding efficiency and it indicates us that the water molecule in PB is involved in their interaction or more likely thallium may exchange with hydrogen from water molecule in PB crystal lattice.

$>$ The decrease in particle size increases the surface area which increases the binding of PB to thallium (IPCS evaluation of antidotes for poisoning by 5 metals and metalloids: Prussian blue Initial Draft-1994).

List of Some Nuclear Disasters in History

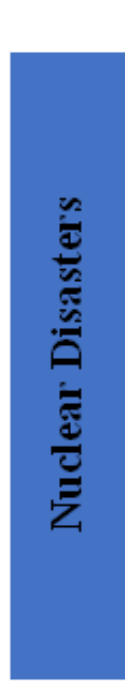

Thr ee Mile Island Nuclear Disaster
The Chernobyl Nuclear Disaster

The Fukushima Daichi Nuclear Accident

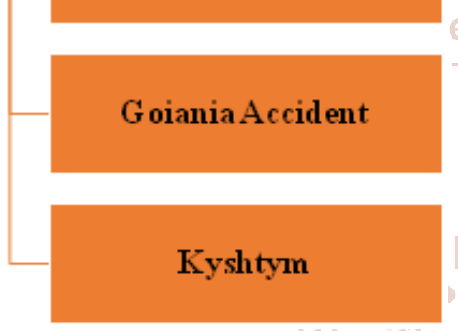

(The Radiological Incident in Goiania, International Atomic Energy, Vienna, 1988), (Jennie Cohen-History worst Nuclear Disasters, 2011), (Pedraza M. et. al., 2013) Types of De-Contamination Procedures

1. External De-Contamination-The procedures which we follow to remove the Radioactive contaminating agents from the external body surfaces are known as the External De-contamination procedure. For ex. Wounds de-contamination, Body Cavities decontamination, Hairy Areas de-contamination, Eyes decontamination, Localized Skin de-contamination. . (Dominguez G. et. al., 2011)

2. Internal De-Contamination- When the radioactive material enters in our body through the breath \& swallowed, absorbed through the skin \& get incorporated into the body cell, tissues \& organs then situation is known as the internal radioactive contamination. It's a treatment only begins when the patient is medically stable \& when the external decontamination of the has been already performed, its removal from the body is mainly performed by the mechanism of adsorption. Hence that's why the whole process is also known as the Internal De-Contamination. For ex. Adsorption of the Radioactive Iodine \& Cesium. . (Dominguez G. et. al., 2011)
List of Some Internal De-Contamination Agent along with their Route of Administration

\begin{tabular}{|c|c|c|c|}
\hline $\begin{array}{l}\text { S. } \\
\text { N }\end{array}$ & $\begin{array}{c}\text { Decorporating } \\
\text { Agent }\end{array}$ & $\begin{array}{l}\text { Route of } \\
\text { administration }\end{array}$ & Radionuclide \\
\hline 1. & $\begin{array}{c}\text { Ammonium } \\
\text { Chloride }\end{array}$ & Oral & Strontium \\
\hline 2. & $\begin{array}{c}\text { Ca-DTPA, Zn- } \\
\text { DTPA }\end{array}$ & I.V. & $\begin{array}{l}\text { Americium, } \\
\text { Plutonium }\end{array}$ \\
\hline 3. & Calcium & Oral & $\begin{array}{c}\text { Radium, } \\
\text { Strontium, } \\
\text { Barium }\end{array}$ \\
\hline 4. & Ca-gluconate & I.V. & Strontium \\
\hline 5. & $\begin{array}{l}\text { Penicillamine- } \\
\text { D }\end{array}$ & Oral & $\begin{array}{c}\text { Cobalt, } \\
\text { Indium, } \\
\text { Palladium } \\
\end{array}$ \\
\hline 6. & $\begin{array}{l}\text { Potassium } \\
\text { Iodide }\end{array}$ & Oral & Iodine \\
\hline 7. & $\begin{array}{l}\text { Potassium } \\
\text { Phosphate }\end{array}$ & Oral & Phosphorous \\
\hline 8. & Prothiouracil & Oral & Iodine \\
\hline 9. & Prussian Blue & Oral & $\begin{array}{l}\text { Cesium, } \\
\text { Thallium, } \\
\text { Rubidium }\end{array}$ \\
\hline 10. & $\begin{array}{c}\text { Sodium } \\
\text { Alginate }\end{array}$ & Oral & Strontium \\
\hline 11 . & $\begin{array}{c}\text { Sodium } \\
\text { Bicarbonate }\end{array}$ & I.V. & Uranium \\
\hline
\end{tabular}

(Office of Public Affairs, U.S. Nuclear Regulatory Commission, Washington, April 2000)

Techniques Used for the Internal De-Contamination of the Radioactive Elements

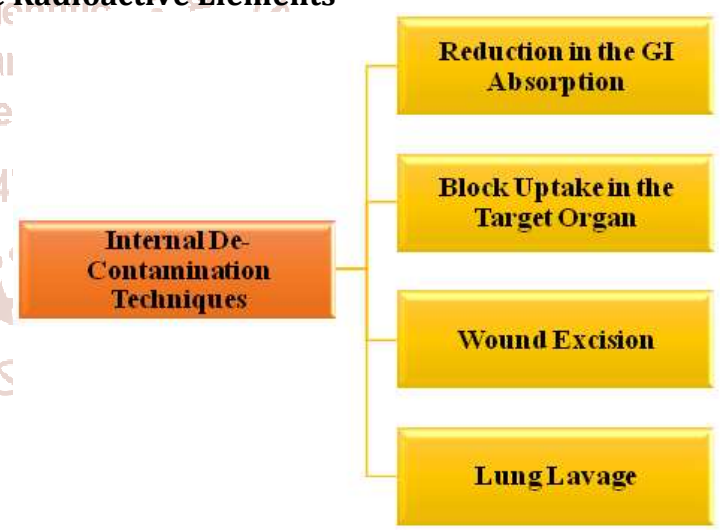

1. Reduction in the GI Absorption- Gastric absorption can be reduced by stomach lavage and emetic agents. These strategies may decrease absorption of radioisotopes if initiated early after gastric contamination, but they also create the risk of aspiration of radioisotopes, leading to respiratory contamination. Laxatives or purgatives, preferably of fast action, will stimulate intestinal motility, and saline cathartics will increase water movement into the intestine and induce removal of contents within 3-6hr. For ex. Barium Sulphate for Strontium \& Prussian Blue for Cesium.

2. Block Uptake in the Target Organ- Patients who were potentially exposed to radioactive iodine should be treated with supersaturated potassium to block thyroid deposition. Potassium iodide competitively blocks thyroid uptake of radioactive iodine and technetium. Potassium iodine is especially recommended for children and pregnant women. For ex. Cal. Gluconate \& Cal. Chloride 
3. Wound Excision- Wound excision may be considered when the wound is contaminated with an isotope that has a very long half-life. For ex. De-Corporation of Plutonium (Dominguez G. et. al., 2011)

4. Lung Lavage-This technique involves the placement of the endotracheal tube in trachea and major bronchi under general anesthesia and the lungs can be lavage with isotonic saline. It is used in the person with chronic lung disease. The use of this technique can be risky in man because of the use of general anesthetic. Thus, this technique should be considered only in high exposures in which a reduction of 25 to $50 \%$ of the dose could be expected to prevent acute or sub-acute effects, such as radiation pneumonitis or fibrosis. (Waller et. al. 2002)

\section{Discussion}

Contamination due to the radionuclide is a major issue in the current era \& due to this the radio-contamination has occurred, hence we need various de-corporating agents to remove this radionuclide contamination as soon as possible As we have already discussed in the literature review that various incidents occurred of radionuclide contamination \& various agents are also preferred to de-corporate this radionuclide contamination. Prussian Blue is one of the agents which was approved by the US-FDA used to decorporate radioactive Cesium \& Thallium. (ICH Q2R1, 1996)

\section{Conclusion}

There is a well-known USFDA approved drugs i.e., Prussian Blue (insoluble) was approved to be used in the emergency situation by USFDA as a potentially safe medicine during nuclear accidents. The marketed formulation that is Radiogardase of the Prussian Blue marketed in the form of the $500 \mathrm{mg}$ capsules at acidic $\mathrm{pH}$. Hence, Prussian Blue Capsule is the marketed formulation which is used for the internal decontamination of the Radioactive Cesium \& Thallium.

\section{References}

[1] Jennie Cohen, History's Worst Nuclear Disasters, 2011(https://www.history.com/news/historys-worstnuclear-disasters)

[2] Office of Public Affairs, United States Nuclear Regulatory Commission, Washington, DC 20555-0001, NUREG/BR-0217, Rev.1, April 2000.

[3] A Brief History of Nuclear Accidents Worldwide; Union of concerned scientists, Science for a healthy planet and the safer world (https://www.ucsusa.org/nuclear- power/nuclear-power-accidents/history-nuclearaccidents\#.W03PRdIzbIV).

[4] Waller, E.A.; Stodilka, R.Z.; Leach, K.andPrud'homeLalonde, L. 2002. Radiation Survey on Decorporation on Radionuclides from the Human Body. DRDC Ottawa TM 2002-042. Defense R\&D Canada - Ottawa. http://www.dtic.mil/dtic/tr/fulltext/u2/a406453.pdf

[5] Domínguez-Gadea, Luis \& Cerezo, Laura. (2011). Decontamination of radioisotopes. Reports of Practical Oncology \& Radiotherapy. 16. 147-152. 10.1016/j.rpor.2011.05.002.(https://www.researchgat e.net/publication/257606532_Decontamination_of_rad ioisotopes).

[6] PIL, Radiogardase Ferric hexacyanoferrate(II), Capsule PIL, by HEYL Chem. Pharm., Fabrik GmbH \& Co. KG, 2008(file:// $\backslash$ Fdswa150 \nonectd $\backslash N 21626 \backslash S \_007 \backslash 200$ 8-04-21 \spl \radiogardase.xml).

[7] ICH, Q2R1, Validation of analytical procedure, Text and Methodology, International conference on harmonization, Geneva. 1996 1-13.

[8] Office of Public Affairs, United States Nuclear Regulatory Commission, Washington, DC 20555-0001, NUREG/BR-0217, Rev.1, April

[9] THE RADIOLOGICAL ACCIDENT IN GOIANIA INTERNATIONAL ATOMIC ENERGY AGENCY VIENNA, 1988(https://www-

pub.iaea.org/mtcd/publications/pdf/pub815_web.pdf)

[10] World major nuclear accidents and their negative impact in the environment, human health and public opinion, by Pedraza Morales J., Nova Science Publishers, 2013.

Web References

[1] 7https://www.drugbank.ca/drugs/DB09104.

[2] https://whatisnuclear.com/radioactivity.html

[3] https://drugsbank.ca/radiogardase/DB09104

[4] https://www.ichguidelines.us.

[5] https://www.medilineplus.gov..html

[6] https://www.drugs.com/sfx/prussian-blue-sideeffects.html 